\title{
KETAHANAN DALAM AIR DAN PELEPASAN NITROGEN \& FOSFOR KE AIR MEDIA DARI BERBAGAI PAKAN IKAN AIR TAWAR
}

\author{
M. Fatuchri Sukadi \\ Balai Riset Perikanan Budidaya Air Tawar \\ Jl. Raya Sempur No.1, Bogor 16154 \\ E-mail: fatuchri_sukadi@yahoo.com
}

(Naskah diterima: 23 Februari 2010; Disetujui publikasi: 27 April 2010)

\begin{abstract}
ABSTRAK
Limbah dan sisa pakan ikan yang tidak termakan dan lepas ke lingkungan air budidaya bisa memberikan kontribusi terhadap penambahan unsur nitrogen $(\mathrm{N})$ dan fosfor $(\mathrm{P})$ ke lingkungan perairan budidaya. Ada 17 jenis pakan ikan komersial yang beredar dan digunakan pembudidaya khususnya oleh pembudidaya keramba jaring apung di Waduk Cirata dan Jatiluhur. Pakan yang beredar tersebut belum diketahui performanya terkait dengan ketahanan dalam air (water stability) serta pelepasan $\mathrm{N}$ dan $\mathrm{P}$ dari pakan tersebut ke air media. Penelitian ini menentukan ketahanan pakan dalam air dari ke-17 pakan tersebut yang dikaitkan dengan pelepasan $\mathrm{N}$ dan $\mathrm{P}$ dari pakan setelah 10 , 20, dan 30 menit pakan direndam dalam air. Hasil penelitian menunjukkan bahwa hubungan kandungan total $P$ dalam pakan berkorelasi linier dengan pelepasan unsur $\mathrm{P}$ ke dalam air. Bila kandungan $\mathrm{P}$ pakan rendah $(<2 \%)$ maka rendah pula $\mathrm{P}$ yang dilepas ke air media. Makin baik ketahanan pakan dalam air, makin rendah $P$ yang dilepas ke dalam air. Ketahanan pakan dalam air yang tinggi masih memberikan kecenderungan tingginya pelepasan $\mathrm{N}$ ke dalam air. Hasil analisis proksimat dari 17 pakan tersebut kandungan proteinnya berkisar antara 26,00\%-29,83\%; total N 4,04\%-4,77\%; dan total P antara $1,38 \%-5,18 \%$.
\end{abstract}

KATA KUNCI: ketahanan pakan dalam air, pelepasan $\mathrm{N}$ dan $\mathrm{P}$, buangan pakan

ABSTRACTS: Water stability and $N$ and $P$ releasing potential of various freshwater feed brands. By: M. Fatuchri Sukadi

Uneaten feed in fish net cage culture in reservoirs is one of aquaculture waste materials and will eventually increase nitrogenous and phosphorous concentrations in the surrounding water environment. There are 17 commercial feeds which are now used by floating net cage farmers in Jatiluhur and Cirata Reservoirs. However, water stability and the releasing potential of $N$ and $P$ of uneaten feed of those feeds into the water media have not been clearly determined and understood. Feeds contain total protein, $N$, and $P$ ranging from $26.00 \%$ to $29.83 \%, 4.04 \%$ to $2.77 \%$, and $1.38 \%$ to $5.18 \%$, respectively. This study dealt with water stability of each feed and its relationship with the releasing pontential of $N$ and $P$ into the water after dipping the feed in the water for 10, 20, and 30 minutes. There was a linier correlation between total $P$ in the feeds and $P$ released into the water. Feeds with total $P$ less than $2 \%$ released less phosphorous into the water. The better water stability of feed, the lesser release of phosphorous into the water. In contrary, there is a trend that feeds with good water stability release higher nitrogenous substance into the water.

KEYWORDS: water stability, release $N$ and $P$, uneaten feed 


\section{PENDAHULUAN}

Residu limbah akuakultur kini makin diperhatikan karena dianggap menjadi faktor penting yang berpengaruh terhadap usaha akuakultur berkelanjutan. Sehubungan dengan makin intensifnya pemberian pakan, besaran limbah kegiatan akuakultur akan makin meningkat. Telah banyak ditengarai bahwa salah satu sumber pencemaran lingkungan budidaya (termasuk eutrofikasi) diakibatkan oleh pelepasan nitrogen $(\mathrm{N})$ dan fosfor $(\mathrm{P})$ dari pakan yang berkualitas rendah. Unsur hara $\mathrm{N}$ dan $P$ sering menjadi hara yang penting dan berperan dalam produktivitas primer dalam ekosistem akuatik (Boyd, 1982). Bila unsurunsur ini berlebihan, perairan bisa menjadi perairan yang eutrofik. Sumber beban hara ini berasal dari sisa pakan yang tak tercerna, metabolit, dan ekskresi ikan (Piedrahita, 1994). Baik $\mathrm{N}$ maupun $\mathrm{P}$, keduanya merupakan unsur penting yang terdapat dalam pakan formulasi untuk pertumbuhan ikan. Kedua unsur ini diperlukan juga bagi pertumbuhan ganggang di perairan. Di perairan tawar, $P$ merupakan unsur hara pembatas dan ortofosfat merupakan bentuknya yang siap tersedia untuk tumbuhan (Chamberlain \& Shapiro,1969 dalam Kibria et al., 1997; Welch \& Lindell, 1980 dalam Kibria et al., 1997; Bostrom et al., 1988 dalam Kibria et al., 1997; Boyd, 1990 dalam Kibria et al., 1997).

Jumlah pakan yang diberikan untuk menghasilkan produk yang maksimal seraya meminimalkan limbah pakan adalah tujuan utama dari setiap aktivitas budidaya ikan yang berwawasan lingkungan demi keberlanjutan usaha. Dalam teknik pemberian pakan yang kurang baik, pakan berlebih mengakibatkan lingkungan air menjadi kurang baik. Selain itu, $\mathrm{N}$ dan $\mathrm{P}$ adalah produk akhir pembebanan yang dilepas dari ikan dan bisa mempengaruhi kualitas air budidaya dan lingkungannya. Secara keseluruhan $\mathrm{N}$ adalah tipe limbah yang predominan berbentuk amoniak dalam ekskresi yang besarannya tergantung pada besaran intake protein atau ketidaktepatan formula pakan yang menyebabkan sintesa protein tidak seimbang (Lazzari \& Baldisseroto, 2008). Produk limbah terdiri atas bahan yang tidak tercerna (seperti P dalam kotoran ikan), nutrien pakan yang tak termanfaatkan (seperti kelebihan protein yang diekskresikan melalui urin dan amonia) dan pakan yang tak termakan. Semua produk limbah itu membebani air secara berlebih dengan nutrien yang tidak dikonsumsi dan menyebabkan perubahan kualitas air, seperti pengkayaan air dan pertumbuhan alga (eutrofikasi). Terlebih bila ketahanan pakan dalam air yang rendah akan meningkatkan pelepasan nutrien tersebut ke dalam media air (Wet, 2010).

Beberapa peneliti mengemukakan bahwa dari asupan $\mathrm{N}$ dan $\mathrm{P}$ hanya sekitar $20 \%$ atau 30\% pakan yang diasimilasi oleh ikan (Ramseyer \& Garling, 1997), sisanya terbuang ke lingkungan dan menjadi penyebab pencemaran. Limbah pakan berupa debu dan pakan tak termakan bisa mencapai $20 \%$ (Beveridge, 1987 dalam Kibria et al., 1997), sedangkan beberapa peneliti lainnya melaporkan sekitar 10\%-30\% hanya dari pakan yang tak termakan ikan saja (Hoelzi \& VensCappell,1980 dalam Kibria et al.,1997; Penczak et al.,1982 dalam Kibria et al., 1997). Banyaknya pakan yang tidak termakan dalam keramba jaring apung mini $(1 \mathrm{~m} \times 1 \mathrm{~m} \times 1 \mathrm{~m})$ tergantung pada besaran ransum harian dan kepadatan ikan yang dipelihara yaitu sekitar 24,43\% (pada kepadatan tinggi, 300 ekor $/ \mathrm{m}^{3}$ ) dan $37,80 \%$ (pada kepadatan rendah, 60 ekor $/ \mathrm{m}^{3}$ ) dengan pemberian ransum 3\% (Insan et al., 2005). Dalam pemberian pakan pada KJA ukuran $7 \mathrm{~m} \times 7 \mathrm{~m} \times 3 \mathrm{~m}$, pakan yang terbuang sekitar 20\%-30\% (Krismono \& Wahyudi, 2002; Azwar et al., 2004). Beberapa penelitian pemberian pakan yang berbasis biologis telah banyak dilakukan untuk menghitung limbah solid dan cair yang diekskresikan ikan akibat pakan yang tidak dicerna dan berakhir pada penghitungan limbah total dari akuakultur (Cho, 2004). Evaluasi berbagai pakan komersil ikan mas berdasarkan hasil analisis proksimat dan performansinya terhadap produksi ikan telah dilakukan terhadap budidaya di kolam air deras (Djajasewaka \& Lim, 1985), sedangkan evaluasi terkait cara pemberian pakannya telah dilakukan oleh Dharma et al. (1985). Namun demikian, kegiatan tersebut tidak mencakup dampak kualitas pakan terhadap pembebanan hara $\mathrm{N}$ dan $\mathrm{P}$ ke air pemeliharaan. Kualitas air sistem resirkulasi di tambak intensif (Azwar, 2003) dan kualitas air buangannya (Wisnawa, 1991) telah diteliti pula, namun kegiatan inipun belum mencakup evaluasi berbagai kualitas pakan yang digunakan terkait dengan kualitas air yang terkena buangan pakan terutama pada budidaya ikan air tawar. 
Pelepasan $\mathrm{N}$ dan $\mathrm{P}$ dari berbagai jenis pakan komersil yang beredar terutama untuk budidaya ikan air tawar di waduk belum jelas informasinya. Pakan yang beredar pada pelaku pembudidaya keramba jaring apung di Waduk Cirata dan Jatiluhur ada sekitar 17 merk dagang dari paling sedikit enam pabrik pakan. Pakan yang beredar dan digunakan di Waduk Juanda sekitar 3.000-4.000 ton per bulan, sedangkan di Waduk Cirata sekitar 8.000-8.500 ton per bulan (Indradjaja, komunikasi pribadi, 2009). Garno (2002) melaporkan di Waduk Cirata mengandung $6.661 .787 \mathrm{~kg} \mathrm{~N}$ dan 1.041 .417 kg $P$ akibat limbah akuakultur yang ada. Sedangkan pada tahun 2006 dilaporkan bahwa kontribusi keramba jaring apung terhadap limbah organik tiga kali lebih besar dibanding limbah domestik dan pertanian (Garno, 2006). Konsentrasi fosfat dan amoniak di waduk ini sangat tinggi di lapisan anoxichypolimnion (Hayami et al., 2008).

Pakan yang beredar dan digunakan oleh para pembudidaya tersebut, walaupun dengan cara penggunaan kantong ganda (kolor), belum diketahui secara jelas keragaman kualitasnya terkait dengan pelepasan haranya ke lingkungan bila pakan tidak termakan oleh ikan. Bilamana keragaan ketahanan pakan dalam air tersebut diketahui diharapkan akan diketahui pula pelepasan hara ke air terutama unsur $\mathrm{N}$ dan $\mathrm{P}$ yang berperan dalam eutrofikasi. Walaupun persentase kejadian terbuangnya pakan yang tidak termakan telah diketahui (10\%-30\%), hubungan antara ketahanan pakan dalam air dengan tingkat pelepasan hara tersebut belum diketahui secara jelas.

Penelitian ini bertujuan untuk mendapatkan hubungan tersebut yang didasarkan pada hipotesis bahwa ada beberapa pakan yang beredar di tingkat pembudidaya yang kualitasnya rendah dan dicirikan oleh ketahanannya dalam air. Selain itu, pakan yang ketahanannya dalam air buruk akan melepaskan hara $\mathrm{N}$ dan $\mathrm{P}$ ke lingkungan air lebih tinggi seperti yang disebutkan Wet (2010).

Hasil penelitian ini diharapkan akan bermanfaat dalam pengelolaan lingkungan budidaya terutama dalam pengendalian pencemaran lingkungan budidaya akibat limbah penggunaan pakan melalui perbaikan mutu pakan yang berwawasan lingkungan. Pengelolaan bisa dilakukan melalui pengaturan peredaran pakan ikan dalam rangka pengelolaan lingkungan budidaya, lahan, dan air untuk budidaya ikan melalui perbaikan kandungan P dalam pakan. Pengelolaan seperti ini sesuai dengan program kegiatan untuk pengembangan teknologi budidaya ikan dalam Agenda Riset Nasional (ARN 8) dan Cara Budidaya Ikan yang Baik (CBIB).

\section{BAHAN DAN METODE}

Pakan yang akan diuji yaitu pakan yang biasa digunakan oleh pembudidaya keramba jaring apung (KJA) di Waduk Cirata dan Jatiluhur. Informasi penggunaan pakan oleh pembudidaya diperoleh dari survai ke kelompok pembudidaya pada kedua waduk tersebut. Jumlah pembudidaya yang menggunakan berbagai jenis pakan dan cara pemberian pakan yang digunakan dipelajari dalam survai ini. Jumlah pakan yang dikumpulkan sebanyak 17 jenis. Informasi sekunder terkait jumlah pakan yang beredar pada kedua waduk tersebut dikumpulkan dari Asosiasi Pengusaha Pakan Ikan atau Gabungan Pengusaha Makanan Ternak.

Ketahanan pakan dalam air (water stability), pengukuran $\mathrm{N}$ dan $\mathrm{P}$ baik pada pakan maupun air ditentukan dengan metode Lovell (1981). Contoh pakan sebanyak $10 \mathrm{~g}$ diukur ketahanannya dalam air $100 \mathrm{~mL}$ di gelas ukur selama 10, 20, dan 30 menit. Kelembaban pakan ditentukan agar penghitungan berbasis pada pakan kering dapat dilakukan. Unsur hara $\mathrm{N}$ dan $\mathrm{P}$ diukur pada air sekaligus dengan mengukur ketahanan pakan dalam air dengan cara Lovell (1981). Air untuk pengujian ketahanan pakan dalam air yaitu aquadest pada suhu kamar $\left(26^{\circ} \mathrm{C}-27^{\circ} \mathrm{C}\right)$. Spektrofotometer Beckman Coulter DU 530 digunakan dalam menentukan persen kandungan $\mathrm{N}$ dan $\mathrm{P}$ dalam air media dan pakan melalui penggunaan larutan baku yang disiapkan sebelumnya. Analisis proksimat pakan dan penelitian laboratorium dilakukan di Balai Riset Perikanan Budidaya Air Tawar, Bogor.

Perbedaan antar ketahanan pakan dalam air diuji dengan program SPS untuk memperoleh pakan yang mempunyai ketahanan rendah, sedang, dan tinggi. Hubungan ketahanan pakan dalam air dengan unsur hara $\mathrm{N}$ dan $\mathrm{P}$ diterangkan dengan hubungan regresi yang dianalisis dengan Excel 2003. 


\section{HASIL DAN BAHASAN}

\section{Pakan yang Digunakan Pembudidaya KJA}

Paling sedikit, ada 6 pabrik pakan yang memasok pakan ikan ke pembudidaya ikan di Waduk Cirata dan Juanda, Jatiluhur. Besaran pasokan pakan ke pembudidaya ikan yang tertinggi beredar ke pembudidaya di Waduk Cirata yaitu pakan komersil sekitar 2.5002.800 ton/bulan, sedangkan ke pembudidaya di Waduk Juanda, Jatiluhur yaitu pakan buatan CP sebesar 1.500-2.000 ton/bulan (Tabel 1). Total input pakan ke Cirata bisa mencapai 8.000-8.500 ton/bulan, sedangkan ke Juanda sekitar 3.000-4.000 ton/bulan (Indradjaja, komunikasi pribadi, 2009). Bilamana tak dilakukan budidaya dengan sistem ganda, pakan yang tidak termakan ikan dan terbuang ke lingkungan perairan bisa mencapai 20\%-30\% (Krismono \& Wahyudi, 2001; Azwar et al., 2004) yang berarti sekitar 1.600-2.400 ton/bulan pakan terbuang ke perairan Cirata dan 600900 ton/bulan terbuang ke perairan Waduk Juanda. Bila persentase pakan yang tidak termakan dan masuk ke perairan dari keramba ganda antara 1\%-2\% seperti yang diteliti Kartamihardja akhir tahun 1990-an (Kartamihardja, komunikasi pribadi, 2009), dan bila rata-rata pakan dipasok ke Waduk Cirata 8.250 ton/bulan maka setiap bulannya akan masuk ke perairan Waduk Cirata sekitar 82,5 ton-165 ton/bulan. Dari pakan yang rata-rata per bulannya dipasok 3.500 ton/bulan ke WadukJuanda, pakan yang terbuang ada sekitar 35-70 ton per bulan.
Dari besarnya jumlah pakan yang digunakan oleh pembudidaya ikan pada kedua waduk tersebut, sangat memungkinkan perairan waduk mengandung $\mathrm{N}$ dan $\mathrm{P}$ yang tinggi seperti yang dikatakan oleh Garno (2002; 2006) dan Hayami et al. (2008). Waduk Cirata termasuk waduk yang perairannya eutropik-hypertropik, sedangkan perairan di Waduk Juanda termasuk mesotropik-eutropik (Sukadi et al., 2007). Nastiti et al. (2001) menyebutkan bahwa pada kegiatan budidaya tahun 1996, penyumbang total $\mathrm{N}$ dan $\mathrm{P}$ terbesar di Waduk Saguling, Cirata, dan JuandaJatiluhur berasal dari kegiatan budidaya ikan (83,63\%-99,97\%) dan kualitas air pada ketiga waduk tersebut telah memburuk.

\section{Analisis Proksimat Pakan}

Hasil analisis proksimat dari 17 jenis pakan yang dikumpulkan, diketahui bahwa pakan tersebut mempunyai kandungan protein antara 26,00\%-29,83\%; total N 4,04\%-4,77\%; dan total P antara 1,38\%-5,1 8\%. Hanya pakan It 1 dan Mf3 yang total P-nya di bawah 2\% (Tabel 2). Kandungan $P$ dalam pakan ini relatif lebih tinggi dari kandungan $\mathrm{P}$ dalam pakan beredar yang diamati Nastiti et al. (2001) yaitu sekitar 0,26\%-1,00\%; sedangkan kandungan $\mathrm{N}$-nya hampir sama sekitar $4,86 \%$. Kisaran $\mathrm{P}$ dari berbagai pakan tersebut lebih besar dibanding dengan kisaran total N. Kandungan total $\mathrm{P}$ tertinggi $(5,18 \%)$ didapatkan pada pakan Mf1, sedangkan yang terendah $(1,38 \%)$ didapatkan pada pakan Mf3. Ratio P:N dalam pakan berkisar dari 1:0,87 sampai dengan $1: 3,07$.

Tabel 1. Besaran input pakan (ton/bulan) untuk akuakultur di Waduk Cirata dan Juanda

Table 1. Feed input quantity (ton/month) for aquaculture in Cirata and Juanda Reservoirs

\begin{tabular}{lcc}
\hline \multicolumn{1}{c}{$\begin{array}{c}\text { Merk } \\
\text { Brand }\end{array}$} & $\begin{array}{c}\text { Waduk (Reservoir) } \\
\text { Cirata }\end{array}$ & $\begin{array}{c}\text { Waduk (Reservoir) } \\
\text { Juanda }\end{array}$ \\
\hline CP & $2,000-2,200$ & $1,500-2,000$ \\
Sinta & $2,500-2,800$ & $1,000-1,500$ \\
Cargill & $2,000-2,200$ & $300-500$ \\
Comfeed & $1,000-1,500$ & $300-500$ \\
Wonokoyo & $800-1,000$ & $400-600$ \\
Guyofeed & $100-300$ & $100-200$ \\
Lain-lain ${ }^{1)}$ & 200 & 100 \\
\hline 1) Grobest, Minafeed dII. & \\
Sumber (Sources): GPMT (27 Agustus 2009)
\end{tabular}


Ketahanan dalam air dan pelepasan nitrogen ....

(M. Fatuchri Sukadi)

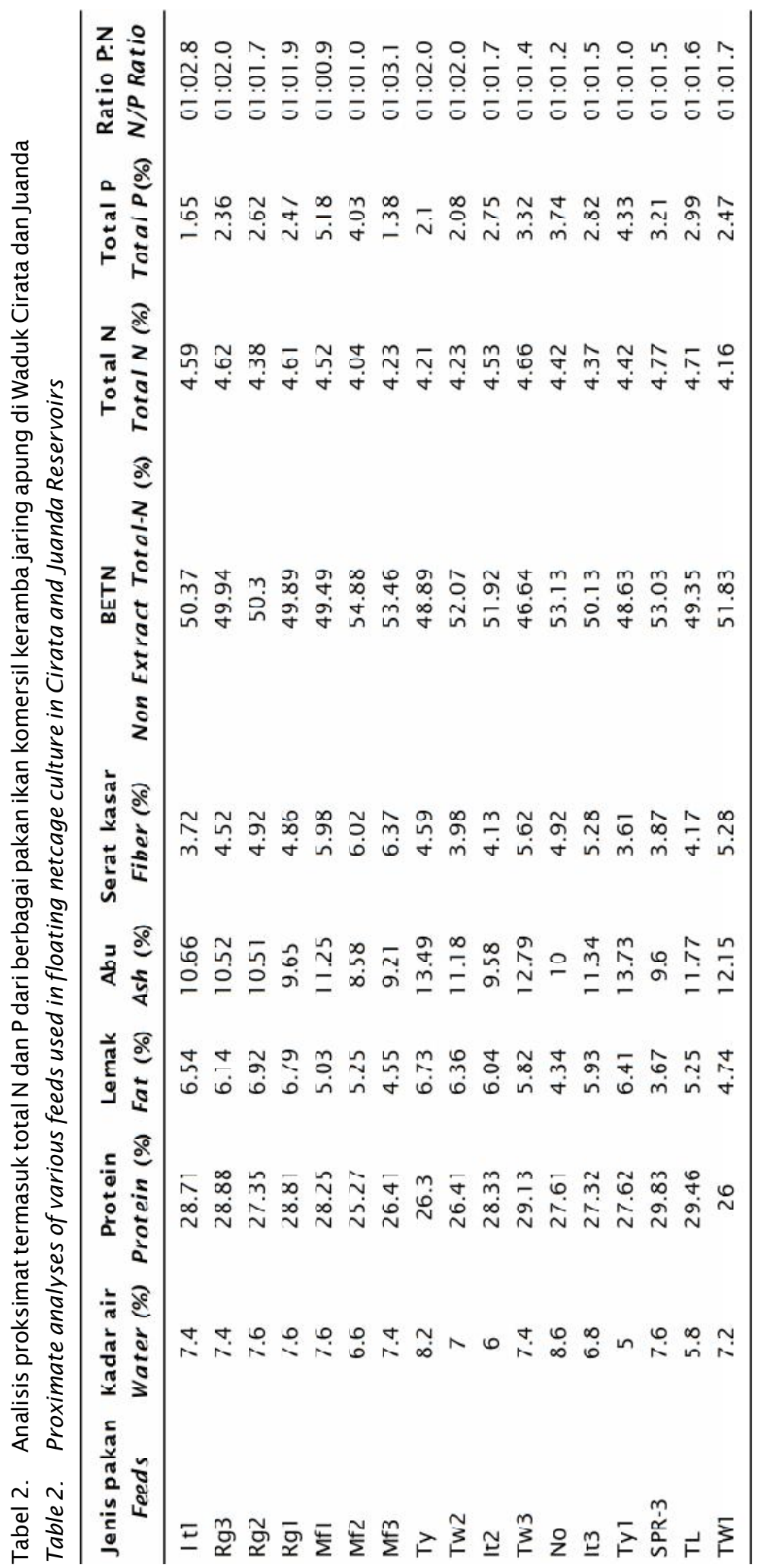




\section{Ketahanan Pakan dalam Air (Feed Water Stability)}

Ketahanan pakan dalam air selama 10 menit berkisar antara 51,06\% sampai 88,60\%; sedangkan dalam 20 menit menurun menjadi antara $46,98 \%$ sampai $84,60 \%$, dan dalam 30 menit menurun lagi hingga antara 48,18\% sampai $83,80 \%$ (Tabel 3). Pakan No diketahui merupakan pakan yang terendah ketahananya dalam air (46,04\%-51,06\%), sedangkan pakan Tyl mempunyai ketahanan dalam air yang tinggi $(83,8 \%-88,6 \%)$ (Gambar 1).

\section{Kelarutan P Pakan ke Dalam Media Air}

Kandungan $\mathrm{P}$ dalam air hasil pelarutan berbagai pakan yang direndam selama 10,20, dan 30 menit menunjukkan kecenderungan bahwa kelarutan P dalam air menurun secara eksponensial dari pakan yang ketahanannya dalam air rendah pada pakan yang ketahanan dalam air tinggi. Dengan nilai $R^{2}$ yang rendah
(0,15-0,32), kurva Gambar 2 memperlihatkan ketiga lama perendaman secara eksponensial, sehingga pakan yang ketahanannya dalam air rendah melarutkan $\mathrm{P}$ ke air lebih banyak. Hal ini menunjukkan bilamana ketahanan pakan dalam air yang rendah, akan meningkatkan pelepasan nutrien ke dalam air seperti yang dikatakan oleh Wet (2010).

Pakan dengan total $P$ yang tertinggi biasanya juga menyebabkan konsentrasi fosfor yang larut dalam air tertinggi (Kibria et al, 1997; Petterson (1988) dalam Kibria et al., 1997). Hal ini terjadi pada pakan Mf1 yang mengandung $5,18 \%$ total $P$ menyebabkan konsentrasi $P$ dalam air setelah direndam 10 menit sebesar $261 \mathrm{mg} / \mathrm{L}$ dan tertinggi dari total $P$ yang dilarutkan jenis pakan lainnya. Sebaliknya pada Mf3 yang hanya mengandung $1,38 \%$ total $P$ melarutkan $P$ sebesar 42 $\mathrm{mg} / \mathrm{L}$ setelah 10 menit pakan dalam air. Meningkatnya pelarutan $\mathrm{P}$ ke air media seiring dengan meningkatnya total $P$ dalam pakan digambarkan dengan hubungan linier (Gambar

Tabel 3. Rataan ketahanan dalam air, water stability (WS) (\%) selama 10, 20, dan 30 menit $(n=3)$ berbagai pakan komersil. Besaran rataan dengan huruf sama pada masing-masing kolom berarti tidak berbeda nyata $(P>0,05)$

Table 3. Means of water stability (WS) (\%) of various commercial feeds after 10,20 , and 30 minutes $(n=3)$. Means with the same letter in each column are statistically not significantly different $(P>0.05)$

\begin{tabular}{|c|c|c|c|}
\hline $\begin{array}{l}\text { Jenis } \\
\text { pakan } \\
\text { Feeds }\end{array}$ & $\begin{array}{c}\text { WS } 10 \text { menit } \pm \text { SD } \\
\text { WS10 minut es } \pm S D \\
(n=3)\end{array}$ & $\begin{array}{c}\text { WS20 menit } \pm \text { SD } \\
\text { WS20 minutes } \pm S D \\
(n=3)\end{array}$ & $\begin{array}{c}\text { WS30 menit } \pm \text { SD } \\
\text { WS30 minut es } \pm S D \\
(n=3)\end{array}$ \\
\hline$|\mathrm{t}|$ & $58.19 \pm 0.32^{c)}$ & $55.24 \pm 0.79^{\mathrm{e})}$ & $52.19 \pm 0.76^{d)}$ \\
\hline $\operatorname{Rg} 3$ & $61.15 \pm 0.40^{f)}$ & $58.15 \pm 0.47^{9)}$ & $57.28 \pm 0.99^{f)}$ \\
\hline $\mathrm{Rg} 2$ & $58.91 \pm 0.23^{d)}$ & $54.66 \pm 0.51^{\text {de) }}$ & $53.53 \pm 0.39^{\mathrm{e})}$ \\
\hline $\mathrm{Rg} 1$ & $59.36 \pm 0.50^{d)}$ & $53.88 \pm 0.37^{d)}$ & $51.74 \pm 0.66^{\text {(d) }}$ \\
\hline Mf1 & $55.01 \pm 0.22^{b)}$ & $52.95 \pm 0.80^{c)}$ & $52.01 \pm 0.18^{d)}$ \\
\hline Mf2 & $60.95 \pm 0.28^{f)}$ & $58.95 \pm 0.20^{\mathrm{gh})}$ & $58.14 \pm 0.30^{g)}$ \\
\hline Mf3 & $60.32 \pm 0.77^{\mathrm{e})}$ & $59.62 \pm 0.44^{h)}$ & $48.18 \pm 0.37^{b)}$ \\
\hline Ty & $59.02 \pm 0.47^{d)}$ & $53.84 \pm 0.32^{d)}$ & $52.28 \pm 0.21^{d)}$ \\
\hline Tw2 & $62.97 \pm 0.11^{g)}$ & $61.23 \pm 0.67^{\mathrm{i})}$ & $59.38 \pm 0.46^{h)}$ \\
\hline It2 & $69.18 \pm 0.22^{i)}$ & $68.68 \pm 0.40^{\mathrm{k})}$ & $66.78 \pm 0.56^{\mathrm{j})}$ \\
\hline Tw3 & $58.96 \pm 0.19^{d)}$ & $56.89 \pm 0.37^{f)}$ & $54.18 \pm 0.48^{\mathrm{e})}$ \\
\hline No & $51.06 \pm 0.37^{\mathrm{a})}$ & $46.98 \pm 0.15^{a)}$ & $46.04 \pm 0.20^{\mathrm{a})}$ \\
\hline It3 & $66.48 \pm 0.48^{h)}$ & $64.52 \pm 0.77^{\mathrm{j})}$ & $61.36 \pm 0.53^{i)}$ \\
\hline Ty 1 & $88.60 \pm 0.00^{\mathrm{k})}$ & $84.60 \pm 0.00^{\mathrm{m})}$ & $83.8 \pm 0.00^{1)}$ \\
\hline SPR-3 & $57.83 \pm 0.35^{c)}$ & $51.56 \pm 0.33^{b)}$ & $51.06 \pm 0.29^{c)}$ \\
\hline TL & $77.03 \pm 0.20^{\mathrm{j})}$ & $71.32 \pm 0.38^{1)}$ & $71.38 \pm 0.36^{\mathrm{k})}$ \\
\hline TW1 & $58.08 \pm 0.55^{\mathrm{c}}$ & $56.76 \pm 0.39^{f)}$ & $48.82 \pm 0.25^{b)}$ \\
\hline
\end{tabular}




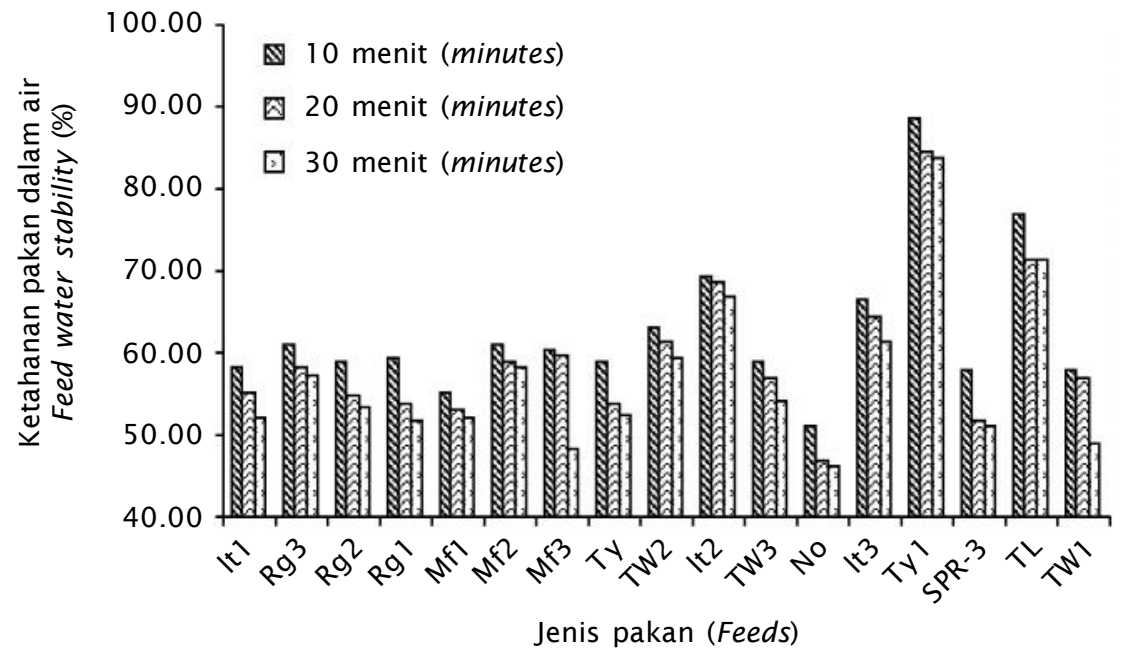

Gambar 1. Ketahanan pakan dalam air (\%) selama 10, 20, dan 30 menit dari 17 macam pakan komersil

Figure 1. Feed water stability of 17 commercial feeds after dipping in the water for 10, 20, and 30 minutes

3). Walaupun demikian, tentunya banyak faktor yang mempengaruhi terlepasnya $P$ ke air media seperti faktor $\mathrm{pH}$, suhu, oksigen, turbulensi air, dan aktivitas mikrobial dalam lingkungan (Kibria et al., 1997). Menurut Kibria et al. (1997), terlepasnya ortofosfat akan lebih tinggi dalam air yang asidik ( $\mathrm{pH} 4)$, sedangkan amonium dipercepat pada kondisi air netral hingga alkalin ( $\mathrm{pH} 7$ dan 10).

Agar pelepasan $\mathrm{P}$ ke lingkungan rendah, pakan terapung merupakan alternatif bentuk pakan yang baik. Pakan terapung selain bisa

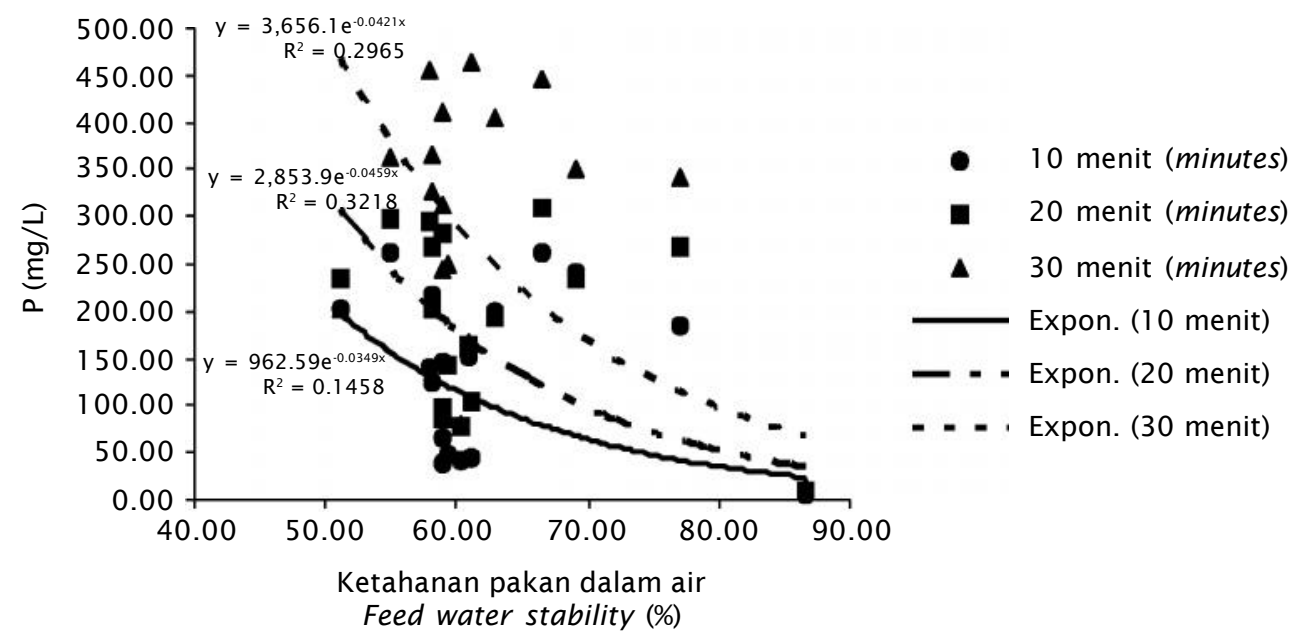

Gambar 2. Hubungan antara ketahanan pakan dalam air (\%) selama 10, 20, dan 30 menit berbagai pakan komersil dengan unsur P yang dilepas ke air media

Figure 2. Relationship between water stability (\%) of various commercial feeds after dipping feed in the water for 10,20, and 30 minutes and $P$ released into the water 


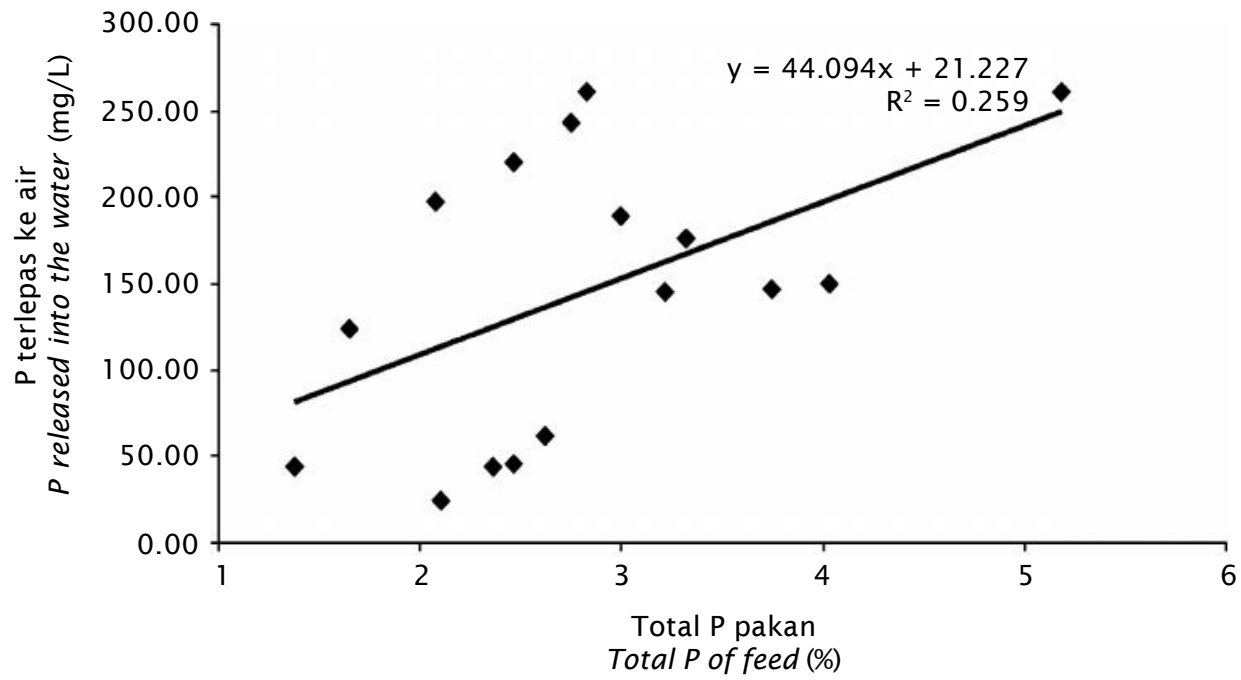

Gambar 3. Hubungan antara total P pakan (\%) dengan pelepasan P ke air media (mg/L) setelah 10 menit pakan dalam air dari 16 jenis pakan

Figure 3. Relationship between total $P$ of 16 commercial feeds (\%) and $P$ released into the water ( $\mathrm{mg} / \mathrm{L})$ after dipping the feeds in the water for 10 minutes

meningkatkan kecernaan terhadap pakan, juga mengurangi jumlah pakan yang tak termakan, memperbaiki ketahanannya dalam air, mengurangi partikel debu dan terlepasnya limbah P ke air media, dan akhirnya mengurangi pencemaran air (Suhenda, komunikasi pribadi, 2009). Pengelolaan lingkungan budidaya salmon di Denmark dilakukan dengan penurunan kadar P dalam pakan menjadi 0,9\%-1,2\% (Piedrahita, 1984).

Bilamana pakan (P 1,38\%-5, 18\% atau ratarata $3,28 \%$ ) yang tak termakan terbuang dari keramba jaring ganda sebesar 1\%-2\% dan masuknya pakan ke perairan Waduk Juanda sekitar 3.500 ton per bulan serta ke Waduk Cirata sekitar 8.250 ton per bulan, maka pakan yang lepas ke lingkungan perairan Waduk Juanda bisa mencapai sekitar 35-70 ton per bulan dan ke Waduk Cirata sekitar 82-165 ton per bulan. P yang lepas ke Waduk Juanda ini setara dengan 4,2-8,4 ton $\mathrm{P}_{2} \mathrm{O}_{5}$, sedangkan yang ke Waduk Cirata setara dengan 9,6-19,2 ton $\mathrm{P}_{2} \mathrm{O}_{5}$. Fosfor yang dihasilkan oleh pelarutan pakan dan feses perlu diwaspadai juga karena biasanya dalam bentuk labil (Kibria et al., 1997) dan siap dimanfaatkan tumbuhan (Butz \& VensCappel, 1982 dalam Kibria et al., 1997) termasuk plankton. Hal ini akan menjadi penyebab utama blooming plankton. Fosfor dalam bentuk labil diketahui dari fraksinya yang diekstrak air dan amonium chlorida ditengarai siap dimanfaatkan tumbuhan (Butz \& Vens-Cappel, 1982 dalam Kibria et al., 1997). Padahal, fosfor dalam pakan dan feses mengandung fosfor yang utamanya dalam bentuk labil (Kibria et al., 1997). Upaya mengurangi kelarutan $P$ dari pakan yang tidak termakan, salah satunya adalah dengan mengurangi kandungan tepung ikan dalam pakan. Ikan mas dengan pakan yang mengandung $10 \%$ tepung ikan mengekskresikan 5,9 $\mathrm{kg} \mathrm{P} / 1.000 \mathrm{~kg}$, sedangkan yang diberi pakan dengan 30\% tepung ikan mengekskresikan 9,6 $\mathrm{kg} \mathrm{P} / 100 \mathrm{~kg}$ (Jahan et al., 2000 dalam Lazzari $\&$ Baldessoretto, 2008).

Bilamana tepung ikan disubstitusi dengan bahan tumbuhan seperti kedelai atau lainnya, $P$ dari tumbuhan mengandung phytin, suatu molekul simpanan $P$ tumbuhan. $P$ phytin ini kurang bisa dicerna ikan. P phytin yang tak dicerna diekskresikan bersama kotoran ikan ke lingkungan (Ramseyer \& Garling, 1977). Ekskresi P yang umumnya 69\%-86\% dari pakan tergantung pada sumbernya yang terkait dengan jenis ikan yang dipelihara dan cara pemberian pakan. Penggunaan fitase dalam pakan ikan menjadi alternatif yang baik untuk mengurangi limbah P (Lazzari \& Baldisseroto, 2008). Selain itu, limbah P yang terkait dengan pakan bisa diminimalkan dengan besaran $P$ 
pakan untuk ikan walaupun mempunyai kelarutan dalam air yang rendah (Ramseyer \& Garling, 1997).

\section{Kelarutan N Pakan ke Dalam Air Media}

Pelarutan $\mathrm{N}$ dari pakan tergantung pada ketahanannya dalam air. Kebalikan dari pelarutan $\mathrm{P}$ dari pakan, maka pelarutan $\mathrm{N}$ ke air dari pakan makin tinggi pada pakan yang ketahanannya dalam air yang lebih rendah (Gambar 4). Ada perbedaan pelarutan $\mathrm{N}$ dan $\mathrm{P}$ ke air dari pakan. Menurut Kibria et al. (1997), pelepasan fosfor akan meningkat dengan menurunnya $\mathrm{pH}$, sedangkan pelepasan amonium meningkat dengan meningkatnya $\mathrm{pH}$. Selain itu, Kibria et al. (1997) menunjukkan bahwa pelepasan $P$ ke air selama 6-8 hari mengikuti kurva polinomial berpangkat 2 , sedangkan pada waktu yang sama pelepasan $\mathrm{N}$ mengikuti pola kurva berpangkat. Walaupun ketahanan pakan dalam air membaik, ternyata pelepasan $\mathrm{N}$ cenderung masih menaik dari ketahanan 10 menit sampai 30 menit. Bisa jadi pengaruh $\mathrm{pH}$ dan temperatur lebih dominan daripada faktor ketahanan pakan dalam air. Hal ini menyebabkan kecenderungan itu terjadi dengan kelarutan $\mathrm{N}$ yang tinggi walaupun pada pakan yang tinggi ketahanannya dalam air.

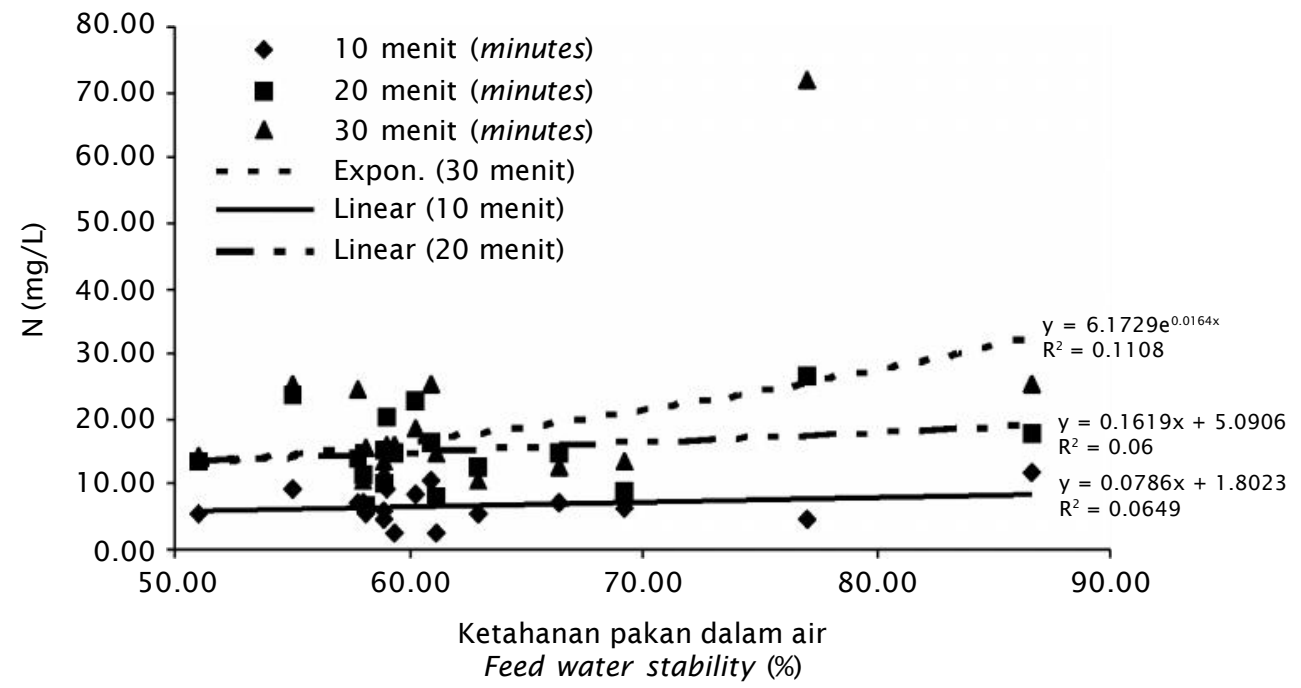

Gambar 4. Hubungan ketahanan pakan dalam air (\%) selama 10, 20, dan 30 menit dengan kandungan $\mathrm{N}(\mathrm{mg} / \mathrm{L})$ yang dilepas ke air media

Figure 4. Relationship between feed water stability (\%) after dipping in the water for 10 ,

20 , and 30 minutes and $N(\mathrm{mg} / \mathrm{L})$ released into the water
Sebagian besar kandungan $\mathrm{N}$ dalam pakan yaitu protein. Protein mengandung $\mathrm{N}$ sekitar 16\%(Lovell, 1981). Fraksi nitrogen bisa berasal dari protein yang larut dan tak larut dalam air (Tonheim et al., 2007). Fraksi nitrogen yang larut dalam air lebih mudah dicerna ikan daripada fraksi nitrogen yang tak larut dalam air. Dibanding larutnya $\mathrm{N}$ dari kotoran ikan, $\mathrm{N}$ yang larut dari pakan yang tak termakan bisa jadi merupakan sumber input utama sebagai limbah padatan ke lingkungan (Kibria et al., 1997). Beragamnya pelepasan $\mathrm{N}$ dari pakan yang berbeda ketahanan pakannya dalam air bisa jadi diakibatkan oleh beragamnya penggunaan sumber protein dalam pakan yang berbeda oleh berbagai pabrikan pakan. Tingginya $\mathrm{N}$ dilepas ke air oleh beberapa jenis pakan yang ketahanan pakannya dalam air tinggi, mungkin disebabkan pula oleh pemilihan sumber protein yang mudah dicerna ikan walaupun juga mudah larut ke dalam air. Kemungkinan lain yaitu adanya $\mathrm{N}$ yang berasal dari bukan protein seperti urea yang dimasukkan ke dalam komposisi pakan. Berdasarkan penelitian terhadap ikan bandeng, terbukti bahwa penambahan urea di bawah $50 \%$ kadar protein pakan bandeng masih memberikan pertumbuhan yang baik (Ahmad \& Rusmaedi, 2005). Dalam pakan yang dikurangi penggunaan tepung ikannya, nilai 
total $\mathrm{P}$ yang diekskresikan ikan mas akan tereduksi, walau sementara itu buangan $\mathrm{N}$ nya meningkat.

Hal ini membuktikan betapa sulitnya memperkirakan adanya hubungan positif antara ketahanan pakan dalam air dengan besaran $\mathrm{N}$ yang dilepaskan ke air media. Beberapa faktor seperti derajat pelepasan unsur $\mathrm{N}$ dari partikel pakan, daya dan derajat cerna, serta derajat penyerapan perlu dipertimbangkan. Hal ini sesuai dengan pendapat bahwa pendekatan biologis dan nutrisional yang tepat dalam menghitung perkiraan output limbah akuakultur akan lebih akurat dan ekonomis dibanding dengan cara pendekatan metode kimiawi atau limnologi (Cho et al., 1991 dalam Cho, 2004; Cho et al.,1994 dalam Cho, 2004; Cho \& Bureau, 1997 dalam Cho, 2004).

Upaya atau strategi mengurangi dampak lingkungan dari kegiatan akuakultur, salah satunya yaitu dengan memperbaiki pakan dan teknologi cara pemberian pakan, di samping pemilihan lokasi yang baik, penghematan penggunaan air dan pengolahan serta mengkonsentrasikan limbah sebelum dilepas ke lingkungan (Piedrahita, 1994).

\section{KESIMPULAN DAN SARAN}

\section{Kesimpulan}

Total input pakan pada kegiatan budidaya KJA di Cirata sekitar 8.000-8.500 ton/bulan, sedangkan ke Juanda sekitar 3.000-4.000 ton/ bulan. Tanpa keramba sistem ganda, pakan yang tidak termakan ikan dan terbuang ke lingkungan perairan (20\%-30\%) sekitar 1.6002.400 ton/bulan ke perairan Cirata dan 600900 ton/bulan ke perairan Waduk Juanda. Dengan keramba jaring ganda pakan tak termakan terbuang sekitar $1 \%-2 \%$, pakan yang dilepas ke lingkungan perairan Waduk Juanda sekitar 35-70 ton per bulan dan ke Waduk Cirata sekitar 82-165 ton per bulan.

Dari 17 jenis pakan yang diteliti, ketahanan pakan dalam air selama 10 menit berkisar antara sekitar 58\%-89\%. Ketahanan ini menurun setelah 20 menit menjadi sekitar 46,98\%-84,60\% dan setelah 30 menit sekitar $46,04 \%-83,80 \%$. Telah ada pakan yang beredar mengandung $P$ dalam pakan yang rendah (1,38\%), setelah 10 menit direndam melepas $\mathrm{P}$ ke air media hanya $42 \mathrm{mg} / \mathrm{L}$.
Sebaliknya, pakan dengan kadar P-nya tinggi $(5,18 \%)$ yang setelah direndam 10 menit melepaskan P ke air media $261 \mathrm{mg} / \mathrm{L}$. Sedangkan kandungan $\mathrm{N}$ dalam pakan yang beredar relatif seragam berkisar antara 4,04\%$4,71 \%$.

Makin tinggi kandungan $\mathrm{P}$ dalam pakan makin tinggi pelepasan $P$ ke media air. Kecenderungan pelepasan berbentuk regresi linier $\left(Y=44,094 X+21,227, R^{2}=0.259\right)$. Dari hubungan antara ketahanan pakan dalam air dengan pelepasan $\mathrm{P}$ pakan ke media air menunjukkan bahwa makin tinggi ketahanan pakan dalam air makin rendah pelepasan $\mathrm{P}$ ke dalam air dari pakan yang telah direndam selama 10,20 , dan 30 menit. Ketiga kecenderungan hubungan ini berupa hubungan eksponensial. Hubungan antara ketahanan pakan dalam air dengan pelepasan $\mathrm{N}$ pakan ke media air sangat kurang memberikan tendensi regresi yang kuat $\left(R^{2}=\right.$ 0,06-0,1).

\section{Saran}

Untuk mengurangi dampak pengkayaan unsur $\mathrm{N}$ dan $\mathrm{P}$ ke media perairan dari limbah pakan yang terbuang, maka penggunaan keramba jaring ganda menjadi sangat penting untuk mengurangi buangan pakan yang tidak termakan ikan ke lingkungan perairan dan pada gilirannya mengurangi pelepasan $P$ ke lingkungan. Berdasarkan rendahnya pelepasan $\mathrm{P}$ ke air, sebaiknya pakan dengan $\mathrm{P}$ lebih rendah dari 2\% yang diperbolehkan digunakan. Pakan apung merupakan alternatif penggunaan pakan untuk mengurangi pelepasan $P$ ke air. Sehubungan banyaknya faktor yang mempengaruhi kelarutan $\mathrm{N}$ dan $\mathrm{P}$ dari pakan ke media air, perlu diteliti diantaranya daya larut, daya cerna, dan konversi pakan dari berbagai bahan pakan terutama sumber protein serta hubungannya dengan kelarutan $\mathrm{N}$ dan $\mathrm{P}$ ke air media.

\section{UCAPAN TERIMA KASIH}

Penelitian ini tidak akan terlaksana tanpa dukungan pendanaan dari hibah Diknas 2009. Terima kasih disampaikan kepada petugas operasional penyaluran dana tersebut serta kepada para teknisi laboratorium kimia dan lingkungan khususnya Lilis Sofiarsih, B.Sc. di Balai Riset Perikanan Budidaya Air Tawar, Bogor yang telah membantu menganalisis sampel pakan dan air. 


\section{DAFTAR ACUAN}

Ahmad, T. \& Rusmaedi. 2005. Pemanfaatan berbagai sumber nitrogen nonprotein pada pembesaran ikan bandeng di laut. J. Pen. Perik. Indonesia, $\mathrm{XI}(1)$ : 51-58.

Azwar, Z.I. 2003. Evaluasi kualitas air pada tambak pemeliharaan udang secara intensif dengan teknik purifikasi dan resirkulasi sebagai upaya mempertahankan produktivitas. Prosiding Seminar Nasional Pengelolaan Lingkungan Pertanian. Surakarta, 21 Oktober 2003. Kerjasama Badan Litbang Pertanian-Puslitbang Tanah dan Agroklimat, Loka Penelitian Pencemaran Lingkungan Pertanian Dengan Fakultas Pertanian Univ. Sebelas Maret Surakarta, hlm. 231-243.

Azwar, Z.I., Suhenda, N., \& Praseno, O. 2004. Manajemen pakan pada usaha budidaya ikan di karamba jaring apung. Dalam A. Sudradjat, S.E. Wardoyo, Z.I. Azwar, H. Supriyadi, dan B. Priono, Pengembangan Budidaya Perikanan di Perairan Waduk: Suatu Upaya Pemecahan Masalah Budidaya Ikan dalam Keramba Jaring Apung. Pusat Riset Perikanan Budidaya. DKP. Jakarta, hlm. 37-44.

Boyd, C.E. 1982. Water quality in warmwater fish ponds. Dept. Fisheries and Allied Aquaculture. Agricultural Experimental Station. Auburn University, AL-USA. Elsevirer Sc. Publ. Co. N.Y., 318 pp.

Cho, Y. 2004. Development of computer models for fish feeding standards and aquaculture waste estimation: A Treatise. In L.E. Cruz Suarez, D. Ricque Marie, M.G. Nieto Lopez, D. Villarreal, U. Scholz, Y.M. Gonzalez. 2004. Avances en Nuticion Acuicola VII. Memorias del VII Simposium Internacional de Nutricion Acuicola. 16-19 Noviembre, 2004. Hermosillo, Sonora, Mexico.

Dharma, L., Suhenda, N., \& Lim, C. 1985. Effect of feeding method of the production of common carp in running water pond. In Lim C. 1985, Fish Nutrition and Feed Technology Research in Indonesia. RICA and RIFF, CRIFI, AARD, p. 122-124.

Djajasewaka, H. \& Lim, C. 1985. Evaluation of commercial feeds for common carp (Cyprinus carpio) cultured in running water ponds. In Lim, C. 1985. Fish Nutrition and Feed Technology Research in Indonesia. RICA and RIFF, CRIFI, AARD., p. 117-121.

Garno, Y.S. 2002. Beban pencemaran limbah perikanan dan eutrofikasi di waduk-waduk di DAS Citarum. J. Tek. Lingk., 3(2): ab-cd.

Garno, Y.S. 2006. Contribution of organic waste from fish culture on degradation of water quality. J. Tek. Lingk., 7(3): 303-310.

Hayami, Y., Ohmori, K., Yoshino, K., \& Garno, Y.S. 2008. Observation of anoxic water mass in a tropical reservoir: The Cirata reservoir in Java, Indonesia. Limnology, 9: 81-87.

Insan, I., Suhenda, N., \& Rusmaedi. 2005. Aspek manajemen pemberian pakan pada budidaya ikan mas dalam keramba jaring apung. J. Pen. Perik. Indonesia, $\mathrm{XI}(1)$ : 25-32.

Kibria, G., Nugegoda, D., Fairclough, R., \& Lam, P. 1997. The nutrient content and the release of nutrients from fish food and faeces. Hydrobiologia, 357. Kluwer Academic Publishers. Printed in Belgium, p. 165-171.

Krismono \& Wahyudi, N. 2002. Analisis pengelolaan KJA sebagai salah satu kegiatan pengelolaan danau dan waduk. Dalam E.S. Heruwati, A. Sudradjat dan S.E. Wardoyo (Eds.). Analisis Kebijakan Pembangunan Perikanan. Pusat Riset Pengolahan Produk dan Sosial Ekonomi Kelautan dan Perikanan, hlm. 75-85.

Lazzari, R. \& Baldisseroto, B. 2008. Nitrogen and Phosphorous waste in fish farming. Inst. Pesca, Sao Paulo, 34(4): 591-600.

Wet, L.de. 2010 . The Pollution solution. http:www.aquanutro.com. 28 September 2009.

Lovell. 1981. Laboratory manual, fish nutrition. Auburn University, 65 pp.

Nastiti, A.S., Krismono, \& Kartamihardja, E.S. 2001. Dampak budidaya ikan dalam keramba jaring apung terhadap peningkatan unsur $\mathrm{N}$ dan $\mathrm{P}$ di perairan Waduk Saguling, Cirata, dan Jatiluhur. J. Pen. Perik. Indonesia, 7(2): 22-30.

Piedrahita, R.H. 1994. Managing environmental impacts in aquaculture. In K. Tanaka, K. Konishi, J.P. McVey, \& M.R. Collie (Eds.). Environmental management in aquaculture. Bull. Natl. Res. Inst. Aquaculture, Suppl., 1: 13-20.

Ramseyer, L.J. \& Garling, D.L. 1997. Fish nutrition and aquaculture waste management. Department of Fisheries and Wildlife Michigan State University East Lansing, MI 48824. 
Sukadi, M.F., Kartamihardja, E.S., Koeshendrajana, S., Maskur, Sukimin, S., Rina, Sasongko, A.S., Murtiati, Priyatna, F.N., Jumhana, D., \& Umar, C. 2007. Panduan teknis pengelolaan perikanan secara bersama pada perairan Waduk di Indonesia. DKP dan ACIAR, $57 \mathrm{hlm}$.

Tonheim, S.K., Nordgreen, A., Høgøy, I., Hamre, K., \& Rønnestad, I. 2007. In Vitro Digestibility of Water-Soluble and Water-Insoluble Protein Fractions of Some Common Fish Larval Feeds and Feed Ingredients, Aquaculture, 262 (2-4): 426-435.
Wisnawa, I.M. 1991. Kualitas air buangan tambak pembesaran udang windu (Penaeus Monodon Fabr.) di instalasi tambak Percobaan Negara Dalam Azwar, 2003. Evaluasi Kualitas Air Pada Tambak Pemeliharaan Udang Secara Intensif dengan Teknik Purifikasi dan Resirkulasi sebagai Upaya Mempertahankan Produktivitas. Prosiding Seminar Nasional Pengelolaan Lingkungan Pertanian. Surakarta, 21 Oktober 2003, hlm. 231-243. 